\title{
Circadian Rhythm of Air-borne Bacteria and Dust Particles in a Mice Breeding Room
}

\author{
Toru OBARA, Nobutaka FUKUYAMA, \\ Korefumi MINAKAMI, Tomoyuki UEDA \\ and Chuhei YAMAUCHI
Institute of Laboratory Animal Science, Faculty of Medicine, Kagoshima University 1208-1, Usuki-cho, Kagoshima 890, Japan.

(Received 10 December 1985/Accested 12 March 1986)

\begin{abstract}
The circadian rhythm of air-borne bacteria and dust particles in a mice breeding room was studied at 1-hour intervals on the first, third and fifth day after accommodation of the animals. The numbers of air-borne bacteria in the room increased day by day after accommodation, and showed a circadian rhythm which went down at about noon and rose with three peaks at about 20:00,1:00 and 8:00. The numbers of dust particles tended to decrease from day to day, and they showed almost the same circadian rhythm as the air-borne bacteria. Correlations between air-borne bacteria and dust particles were not significant for each particle level on the first day, but were significant for all the particle levels of $0.3,1,2$, and $5 \mu \mathrm{m}$ at the third day, and were also significant at particles levels of $0.5 \mu \mathrm{m}$ or more on the fifth day.
\end{abstract}

\section{マウス飼育室の空中細菌及び粉塵の日内変動}

小原徽・福山伸隆・水上惟文・

上田智之·山内忠平

\section{鹿枈易大学矤学部附属動物実験施設}

空気中の 細菌は一般に 粉塵に 付着して浮遊している といわれ，また空中細菌と粉塵とは密接な関係がある

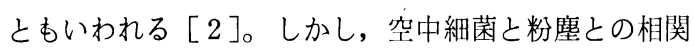
関係については明らかにされていない。一方，実験動 物施設では, 空気清浄度の 評洒あるいは監視のために 空中細菌数の測定がしばしば行われ $[3,4,6,9,10]$, また実験動物施設の落下細菌数の基準值 [12] も示され ている。しかし，動物室の空中細菌には多くの変動要
因があるので [1，7]，いまだ十分な解析は行われず， その測定方法についても疑問な点が多い。そてで，わ れわれは各種環境要因をできるだけ少なくした条件下 でマウス搬入後における飼育室の空中細菌数と粉塵数 の日内変動を遠隔測定し, かつ空中細菌数之粉塵数之 の相関関係について検索したので報告する。

実験には, 空調の給気系に高性能フィルターを組み 込んだ飼育室 $(3,200 \times 2,900 \times 2,370 \mathrm{~mm})$ を用い, 環境 
条件は温度 $21 \pm 1{ }^{\circ} \mathrm{C}$, 相対湿度 $55 \pm 5 \%$, 換気回数 10 回, 照明時間 12時間（午前 7 時点灯, 午後 7 時消灯) に設定した。な抢，飼育室は使用前に床及び壁等を清 掃後，中性洗剂を用いてブラシで充分に洗浄した。そ の後, 次亜塩素酸ナトリウム（ピューラックス，オー ヤラックス社製）之両性界面活性剂（テゴー51，日本 商事社製）を用いて 1 週間消毒し，十分な清浄度を維 持しているととを確認したのちに使用した。すなわち， 動物搬入前の 室内の空中細菌数は $0 \sim 1$ 個, 粉塵数は $5 \mu \mathrm{m}$ レベルで 0 個, $2 \mu \mathrm{m}$ で 8 個, $1 \mu \mathrm{m}$ で 98 個, $0.5 \mu \mathrm{m}$ で 608 個， $0.3 \mu \mathrm{m}$ で7, 201個ときわめて高い清浄度が維 推されていた。動物は 8 〜週秢のS P F の ddy マウ 又雌 400匹を使用し，オートクレーブ減菌した床敷約 40 $\mathrm{g}$ をいれたプラスチックケージに，それぞれ 5 匹ずつ を収容した。

空中細菌と 粉塵の 測定にあたっては，ヒトの出入に よる影響を除くために，慨と水は 1 週間にわたって自 由に摄取できるように準備し，実験期間中飼育室内に 1 回む入室することなく, 室外から測定した。空中浮 遊細菌の捕集は, 山崎ら [11] の方法に準じて Pinhole Sampler を用い，それを少々改変して実施した。すな
わち, ガス減菌した直径 $20 \mathrm{~mm}$, 長さ $2 \mathrm{~m}$ のゴムホース を飼育室の 壁に設けた直径 $25 \mathrm{~mm}$ の孔から出してピンホ ールサンプラー（三基社製）につなぎ， 2 分間に $53 \ell$ の 空気を吸引して，トリプトソイ寒天培地（笨研）を入 れた内径 $90 \mathrm{~mm}$ のシャーレに 吹き付けた。捕集後は好気 的に， $37^{\circ} \mathrm{C}$ で 48 時間培養した後形成されたコロニー数 を数えた。な挔，空中細菌の捕集場所は飼育室中央の 床上 $1 \mathrm{~m}$ とし, サンプリングはマウス般入後 $1,3,5$ 日目に 1 時間間隔で 24 時間連続測定した。一回の測定 で 3 回のサンプリングを行い，その平均を各時間ごと の空中細菌数とした。空中粉塵は光散乱式パーティク ルカウンターとデジタルプリンター（リオン社製）を 用いて測定した。すなわち, 空中細菌の 捕集と同様に して, 直径 $10 \mathrm{~mm}$, 長さ $2 \mathrm{~m}$ のビニールホースを, 飼育 室の壁に設けた孔から出してパーティクルカウンター に接続し, 飼育室中央, 床上 $1 \mathrm{~m}$ の空気を 2 分間に $1 \ell$ 吸入し，0.3，0.5，1，2 及び $5 \mu \mathrm{m}$ の粒子径別の 粉塵 数を，搬入後 $1 ， 3$ および 5 日目に 1 時間ごとに 24 時 間連続測定した。データは 3 点移動平均法により, 時 刻別の変動を経日的にもとめ，また空中細菌と粉鹿と の相関係数を求めた。

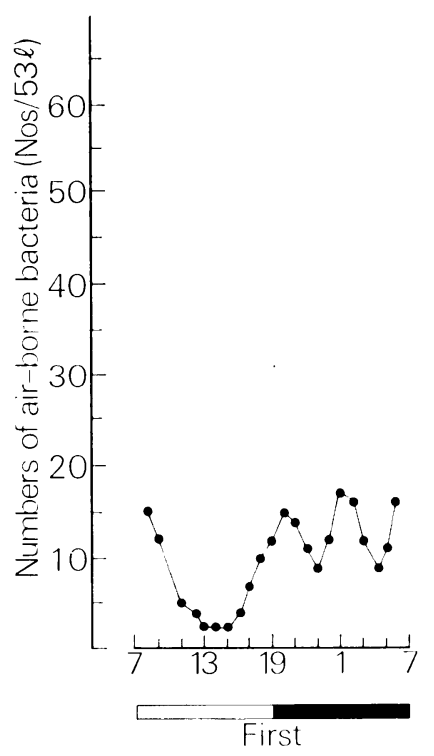

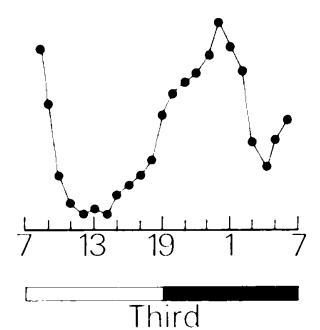

Days after accommodation Clight period

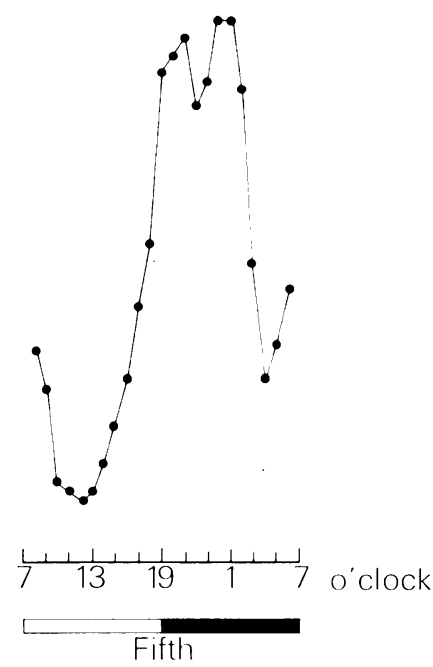

Fifth

Fig. 1 Circadian rhythm of air-borne bacteria in a mice breeding room 
Table 1. Numbers of air-borne bacteria in a mice breeding room measured at hourly intervals on the first, third and fifth day after accommodation of animals

\begin{tabular}{|c|c|c|c|c|}
\hline \multirow{2}{*}{\multicolumn{2}{|c|}{$\begin{array}{l}\text { TIME } \\
\text { (o'clock) }\end{array}$}} & \multicolumn{3}{|c|}{ Days after accommodation } \\
\hline & & First & Third & Fifth \\
\hline \multirow{12}{*}{ light period } & 7 & $15 \mathrm{a}$ & 20 & 22 \\
\hline & 8 & 25 & 30 & 35 \\
\hline & 9 & 4 & 9 & 12 \\
\hline & 10 & 7 & 4 & 9 \\
\hline & 11 & 3 & 4 & 7 \\
\hline & 12 & 3 & 2 & 7 \\
\hline & 13 & 1 & 1 & 8 \\
\hline & 14 & 1 & 3 & 10 \\
\hline & 15 & 3 & 3 & 14 \\
\hline & 16 & 8 & 5 & 20 \\
\hline & 17 & 10 & 6 & 27 \\
\hline & 18 & 12 & 8 & 36 \\
\hline \multirow{12}{*}{ dark period } & 19 & 13 & 9 & 42 \\
\hline & 20 & 19 & 22 & 83 \\
\hline & 21 & 10 & 13 & 44 \\
\hline & 22 & 10 & 14 & 48 \\
\hline & 23 & 11 & 25 & 58 \\
\hline & 24 & 19 & 17 & 53 \\
\hline & 1 & 22 & 26 & 69 \\
\hline & 2 & 8 & 17 & 59 \\
\hline & 3 & 7 & 9 & 28 \\
\hline & 4 & 8 & 8 & 13 \\
\hline & 5 & 15 & 7 & 20 \\
\hline & 6 & 22 & 19 & 38 \\
\hline
\end{tabular}

a : Each number represents the average value from three samples per one measuring time, and represents the numbers of bacteria per 531 of air removed by vacuum for 2 minutes.

空中細菌数：マウス搬入後， $1 ， 3$ および 5 日目にお ける飼育室内の時刻別の空中細菌数は Table 1 亿, ま た， 3 点移動平均法による日内変動は Fig. 1 亿示す。 室内の 空中細菌数は マウス搬入後 1 日目で $1 \sim 25,3$ 日目で $1 \sim 30, \quad 5$ 日目で $7 \sim 83$ と経日的に増加し，と くに5日目では各測定時刻とも著しく增加した。この ように経日的な菌の增加は, 動物般入後の室内におけ る細菌の増加と関連したものであろう。すなわち，動 物の粪尿由来の 細菌が経日的にケージ内で増加し, 動 物の行動によって室内に 飛散したものと考えられる。
また，日内の時刻別には，それぞれの測定日において 朝 8 時前後, 消灯後の 20 時前後 および深夜の 1 時前後 に增加する 3 峰性の変動を示した。乙の傾向は動物搬 入後の 1,3 抢よび 5 日目の空中浮遊細菌数について 普遍的にみられた。1 日日では13及び14時に最小值の 1 個を示し, 8 時に最大值の 25 㑬を示し, その間に 25 倍 の差がみられた。同様な 1 日内の最小値と最大值との 差は 3 日目では 30 倍, 5 日目では 12 倍であった。この ように, マウス室内の空中細菌が, 昼の12時前後にあ っとあ少なく，その後いくらかの変動はあるが，夕刻 から朝にかけて 3 峰性に增加する現象は, 夜行性であ るマウスの自発行動および摄食行動と大きな関係があ るものと考えられる。

これまでの 報告によると, 動物飼育室の 空中細菌は ラットでは夜間に増加する日内変動をみとめたとの報 告ああるが，マウスでは日内変動をみとめなかったと いう報告 [10] あある。本実験のマウス室での結果は, 空中細菌が 朝の点灯前後, 夜の消灯直後及び 深夜に増 加する 3 峰性の日周リズムのあるととを示し, 前者の 説を支持するあのである。岡ら［8]は，ママウスの自発 運動量が暗期 および 明期の移行期および深夜に增加す る 2 または 3 峰性の 日周リズムの あることを報告して いるが，本実験の結果もマウスの自発運動の日周リズ ムと緊密に関連したようなパターンを示していた。

空中粉鹿：Fig. 2 はマウス飼育室における動物搬入 後 $1,3,5$ 日日の 粒子径別 - 粉塵数を 3 点移動平均 法により示した。0.3，0.5，1 $1 \mu \mathrm{m} レ$ レ゙の小さな粉塵 数は 3 日日までは減少したが，5 日目は僅かに 增加す

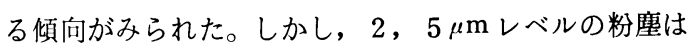
3 日目以後も減少の傾向を示した。乙のととは, 初期 には床敷が 乾燥して 居住性がよいために動物が好んで 活動する傾向にあり，そのために 飼育室の 粉鹿量む增 加したものと思われる。しかし, その後, 床敷が賴尿 等で湿润してくると比較的大きな粉座は飛散し難くな るのではないかと考えられる。

粉塵の日内変動においては，おおまかにみて 尽間の 12 時前後が むっとあ少なく, 夜の 20 時前後, 深夜 1 時 前後 および 朝の 8 時前後に 増加する 3 峰性の変動を示 した。この傾向は 1 日目では各粒子径の粉鹿で顕著に みとめられたが, その変動パターンは日数の経過とと 屯にやや小さくなる傾向を示した。乙のようにマウス 室内の粉塵が是間に少なく, 夕刻, 深夜抢よび朝に增 加するのは, 前述の空中細菌之同様に動物の自発行動, 掑慨行動に関係するあのであろう。 


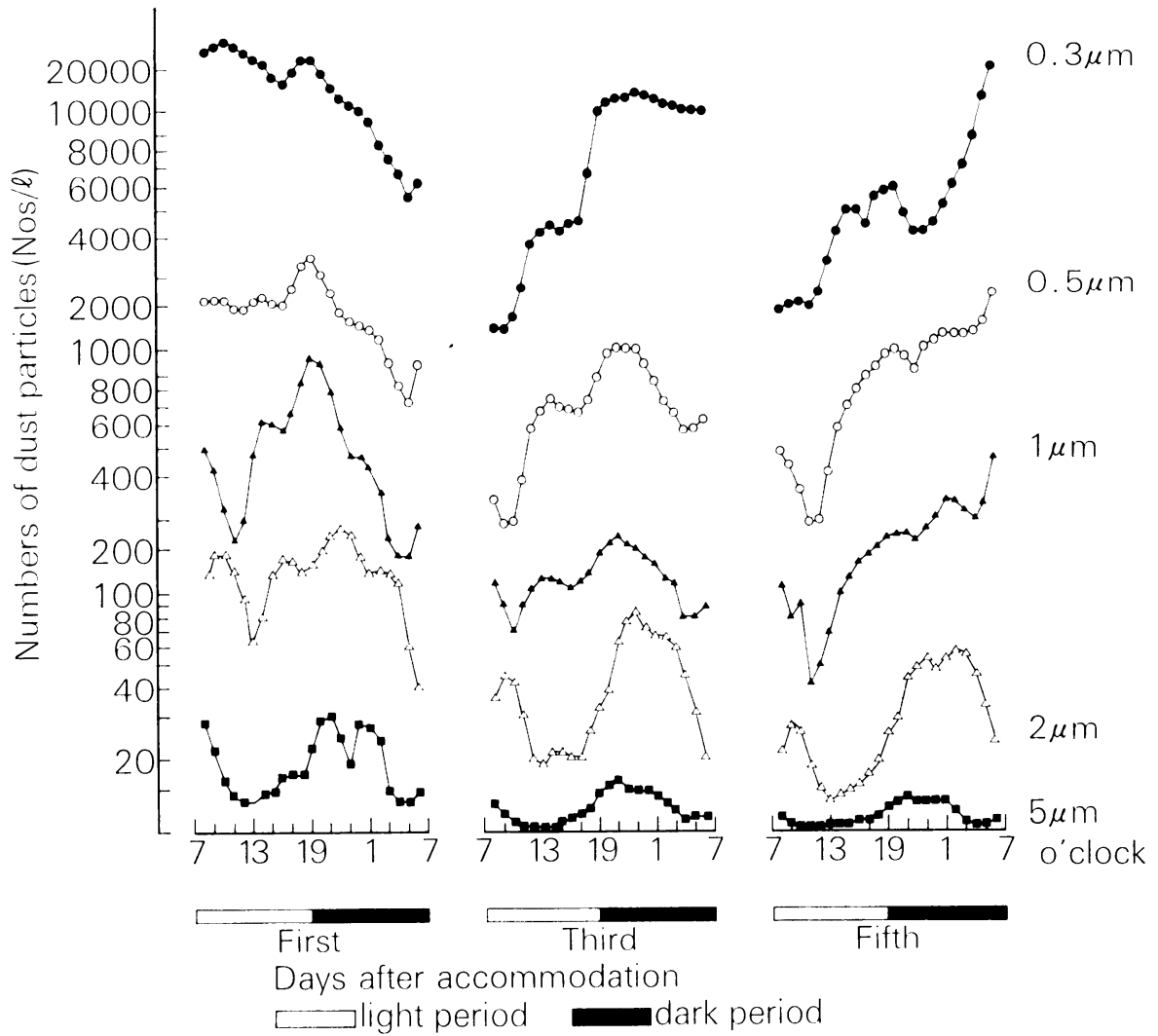

Fig. 2 Circadian rhythm of dust particles in a mice breeding room

空中細菌と粉塵との相関：Table 2 は動物搬入後 1 , 3 および 5 日日における 空中細菌之精子径別粉塵数之 の相関係数 およびその有意差の有無について示したも のである。動物搬入 1 日目ではいずれの粒子径レベルで あ有意な相関はみられなかった。この原因は床敷が乾 燥して飛散する粉塵富が多いとと，減菌した床敷，飼 育器具を使用したためにまだ細菌の增殖が少なかった ことに関係するあのであろう。 3 日目では $0.5 \mu \mathrm{m}$ レべ ルを除くすべての粒子レベルで $5 \%$ の危険率で有意な 相関がみられた。乙れは粉塺の飛散量が 1 日目よりやや 少なくなり，細菌の増殖数あやや多くなり，乙れらの両 因子が同様な日内変動パターンを示していることに関 係していると考えられる。5日目においては，2 および $5 \mu \mathrm{m}$ レベルではきわめて高い相関が みとめられ， 0.5 および $1 \mu \mathrm{m}$ レベルでも $5 \%$ 危険率で有意な相関がみと められた。しかし， $0.3 \mu \mathrm{m}$ レベルでは有意な相関はみ
Table 2. Correlation between numbers of air-borne bacteria and dust particles in a mice breeding room

\begin{tabular}{c|ccc}
\hline \multirow{2}{*}{$\begin{array}{c}\text { particle size } \\
\text { of dust }(\mu \mathrm{m})\end{array}$} & \multicolumn{3}{|c}{ Days after accommodation } \\
\cline { 2 - 4 } & First & Third & Fifth \\
\hline 0.3 & $0.323 \mathrm{~ns}$ & $0.422^{*}$ & $0.169 \mathrm{~ns}$ \\
0.5 & $0.030 \mathrm{~ns}$ & $0.283 \mathrm{~ns}$ & $0.525^{*}$ \\
1 & $0.177 \mathrm{~ns}$ & $0.529 *$ & $0.703 *$ \\
2 & $0.315 \mathrm{~ns}$ & $0.724 *$ & $0.961 * *$ \\
5 & $0.115 \mathrm{~ns}$ & $0.755^{*}$ & $0.928^{* *}$ \\
\hline ns : not significant. $*: \mathrm{p}<0.05, * *: \mathrm{p}<0.01$
\end{tabular}

られなかった。乙れは，5 日目に 空中細菌数は著しく 增加し， $1 \mu \mathrm{m}$ 以上の粉鹿はやや減少し，とあに典型的 日内変動をしていることに関連するものであろう。こ 
のように, 大きいレベルの粉鹿と空中細菌との間に相 関があるのは, 空中細菌の 粒子の大きさは $1 \sim 28 \mu \mathrm{m}$ (平均 $12 \mu \mathrm{m}$ ) の範网にあるといわれること [2], パー ティクルカウンターで吸引测定した 1,2 および $5 \mu \mathrm{m}$ の粉塵のなかには紐菌も吸引して测定していることが

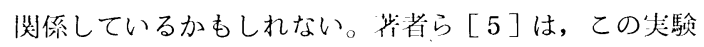
とは別に動物施設洗浄室で使用ずみの污染ケージ処理 作業中の空中細菌之粉塵重量, 粉塵の粓子径別の粉塵個 数との相関について 検索した。そこでは, 空中細菌数 と粉塵重量との間には相関はみとめられなかったが, 空中細菌と 2 および $5 \mu \mathrm{m} レ$ ベの粉塵個数との閒には 有意な相関がみとめられた。いずれにしても，1〜 5 $\mu \mathrm{m}$ レベルの粉塵と空中䋖菌とが動物搬入後 3 日以降に おいて有意な相関があることは泩目すべきであろう。

S P F 動物施設では, 飼育環境の 微生物的清浄度の 監視のために，空中細菌の測定が広く行われているが， 本実験の結果では, 動物搬入後の日数, 測定時刻が空 中細菌数と大きな関係のあることを示している。また， これらのほかに, 空中細菌は動物の収容密度, 温度, 湿度, 換気回数, ケージ交换後の日数之大きな関係の あることも知られている $[1,7]$ 。したがって, 空中 細菌测定 結果には, サンプリングの方法, 暴露特間, 塪地の種類, 培養胡間などとともに, 少なくとも温度, 湿度, 換気回数, 収容密度, 测定時刻等を示しておく ことが必要である。一方, 空中紐菌と粉塵とは密接な 関係のあることが明らかになったので，空中粉鷹の测 定も動物室の清浄度モニタリングの一指標になるもの と考えられる。将来, 上記の各種要因に重みづけした 一定の関係式で表示する方法が開発されることによっ て，はじめて実用的な評価方法が確立されるものと考 えられる。
要

\section{約}

マウス飼育室の空中細菌数と粒子径別の粉塵個数を, 動物般入後 $1 ， 3$ および 5 日目に 1 昉間ごとに検索し た。空中細菌は動物搬入後の日数とともに增加し， 1 日のなかでは正午前後がもっとも少なく，20時前後， 深夜の 1 時前後および 8 時前後に増加する 3 峰性の日 内変動を示した。粉塵は経日的に減少する傾向を示し たが, 空中細菌と同様の日内変動パターンを示した。 空中細菌之粉塵との間には，動物搬入 1 日日では相関 をみとめなかったが， 3 日目では，0.3，1，2および $5 \mu \mathrm{m} レ$ ベの粉塵との間に， 5 日目では $0.5 \mu \mathrm{m}$ 以上の 粉塵との間に有意な相関がみとめられた。

木実験は, 文部省科学吥究費一般吥究 (B) 課題番 号60480486の一部として実施したものである。

\section{文献}

[1] Besch, E. L. (1980). Laboratory Animal Science. 30, 385-389.

［2］早川一也・都築正和（1974）。空気調和のための空気清 浄, pp. 371-418. ソフトサイエンス社, 東京.

[ 3 ] 本田登美夫 (1984). 実験動物技術, 19，48-52.

[4] 松本恒弥 (1980). 実験動物技術, 15, 1-17.

[5] 水上䊒文・小原 徹 - 山内忠平 (1986). 実験動物. 35 , 293-297.

［6］ 小原 徽・松山賢忠・藤田省吾 - 山内忠平 (1979). 実 験動物, 28, 79-83.

［7] 小原 徹・今田中伸哉 (1984). 実験動物技術, 19, 1-6.

[8] 岡 基・斉藤 徽・高橋和明 (1984). 哭医医科学と統 計利用, No. 13-19.

［9］大西絹一・浜田佑二 (1981). 実験動物技術，16，119122.

[10］高坦善男·野口午郎 (1968). 実験動物, 17, 109-117.

[11］山崎省二 (1975). ジャパンフードサイエンス, 14, 3643.

[12］実験動物施設基準研究会 (1983). ガイドライン一一実験 動物施設の建築および設備—昭和58年版, pp. 50-51, 清至書院, 東京. 